\title{
帯広地域土袞腐植区分図の作成方法
}

\section{Mapping Method of Soil Organic Matter Content of Obihiro Area using Landsat TM Data}

\author{
岡本 勝男*, 福原 道一* \\ 畠中 哲哉** \\ Katsuo OKAMOTO, Michikazu FUKUHARA \\ Tetsuya HATANAKA
}

\begin{abstract}
We made the soil organic matter content (hereinafter referred to as O.M.) map of Obihiro Area, Hokkaido, using Landsat TM data. The aim of this paper is to present a making method of the map. The O.M. of each site is derived from the correlation between measured O.M. in the field and CCT count of TM band 3. The O.M. of vegetation-covered cropland is estimated from CCT count of TM band 3 on the soil line transformed by the soil index method (Fukuhara et al., 1979). The map consists of 18 sheets and covers whole cropland of Obihiro Area $(1,083,000 \mathrm{ha})$. The map is characterized by two points as follows; (i) grid cell size is $25 \mathrm{~m} \times 25 \mathrm{~m}$, (ii) the O.M. is devided in to 7 classes and shown on $1: 50,000$ topographical maps in 7 colors.
\end{abstract}

概要：ランドサット TM データ（バンド $3 ： 630 ６ 90 \mathrm{~nm}$ ）の CCT 值と実測した土壌腐植含量（\%）との関係 を用いて帯広地域（十勝支庁全域）の畑地表土の腐植含量を推定し，土塂腐植区分図を作成した。作成した腐植 区分図は(1) 1 画素の大きさを $25 \mathrm{~m}$ 四方にし，(2)腐植含量の割合を縮尺 $1 ： 50,000$ 地形図上に 7 色で表現・印刷 した。本腐植区分図は，土㙵の特徵を围場単位で把握し，畑地灌溉や排水改良等土地基盤整備，土堙改良，作付 け計画，肥培管理等へ活用することを目的として作成したものである。

\section{はじめに}

腐植とは，有機物が主として微生物の作用により分 解生成した有機物質である。その量と質が土溒生成と 密接に関係しているので, 土壌の窒素供給量や水分環 境の指標として重要である。帯広地域では, 従来, 土 地基盤整備・改良事業の基準的な土壤図として「十勝 管内土壤分類図 $\left.{ }^{6}\right\rfloor$ が広く使われてきた。しかし，これ は $500 \mathrm{~m}$ 四方 (25ha) に 1 点の試坑に基づき地形を見な がら作られている。そのため, 区画された範囲の中に は土㙵名と異なった土堙が含まれることになる。した がって, 土地基盤整備事業や土壌診断事業の資料とし

\footnotetext{
* 農林水産省農業環境技術研究所

**農林水産省草地試験場
}

「写真測量とリモートセンシング」Vol. 29,No.6, 1990
て精密な腐植含量図が事業関係者から望まれてきた。 一方，ランドサット TM データの利用により，大縮尺 土壌眓の作成が可能になっている。畠中ら ${ }^{5)}$ はランド サット TM バンド $3(630 \sim 690 \mathrm{~nm}$ : 赤色, 以下ランド サット TM バンド n を TMnのように略す) のデー夕 を使って畑地表土の腐植含量を高い精度で推定し, 図 化できることを示した。畠中らによると土壌腐植含量 を縦軸, TM 3 の CCT 值を横軸にとって観測点をプ ロットすると, 各点は土㙵型によらずほぼ直線上に並 んで負の相関関係を示す。そこで，この関係を利用し て土壤腐植含量を推定した。

ランドサット TM データから腐植含量を推定でき

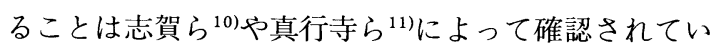
る。志賀らは北海道空知南部の水田および畑地の腐植 含量区分図を作成した。真行寺らは千葉県北総火山灰 台地の腐植含量区分図を作成した。

われわれは，带広地域（十勝支庁全域）を対象に既 
存の土袞図 ${ }^{6)}$ を補完するためにランドサット TM デー 夕から土㙵腐植区分困を作成した ${ }^{4,9)}$ 。本論文では，腐 植区分四の具体的な作成方法および腐植含量推定方法 の改良点について報告する。なお，ここで報告する推 定方法は帯広地域に限ったものであるので, 他地域で 行うには推定式を作り直す必要がある。

\section{1. 作成方法}

\section{(1) 対象地域と腐植含量データ}

北海道十勝支竹内の全市町村 108.3 万 ha $の$ 畑地を 対象とした。腐植含量值は地力保全基本調査試坑地点 (30地点)における土層 $25 \mathrm{~cm} の$ 加重平均値を用いた。

\section{（2）使用したランドサット TM データ}

使用したTM デー夕はパスーロウが106-30と 106-31で，以下の撮影日のものである。

1984年 5 月 21 日：土壤腐植含量計算用

1985年 5 月 24 日：土堙腐植含量計算用

1985年 7 月27日：土地被覆分類補完用

1985年 10 月15日：土地被覆分類用

带広地域では例年 5 月は, 土壤が乾燥し, かつ畑地 が作付け前または作付け直後で裸地状態になってい る。1984年 5 月 21 日は 10 日前から，1985年 5 月 24 日は 8 日前からそれぞれ降水量が観測されていない7,8)。ま た，両日とも土㙵水分 ( $\mathrm{pF}$ 值) は2.16 2.82である。 したがって; 土埣表面は風乾状態であり，土塞水分の 影響はないと考えてよいので, 両日のデータから土畩 腐植含量を計算した。また，1985年のデータでは植生 が覆うため土壌腐植含量を推定できない部分につい て，1984年のデータでできるだけ補完した。土地被覆 分類に際しては，1985年10月のデータでは対象地域の 一部が欠けてしまうため，7月のデータで補完した。

\section{（3）土㙴腐植含量区分值の推定方法}

土壌腐植含量区分值の推定方法は概ね畠中らの手 順 ${ }^{5}$ に従ったが，以下の点を改良して用いた。

(1) TM3と腐植含量はリニアな関係よりも対数曲 線の方がよく合うことから，腐植含量の推定には $\mathrm{TM} 3$ の CCT 值の対数值（以下 TMn の CCT 值 の対数值を $\log \mathrm{TMn}$ と略す）を使った。

(2) 畠中らは裸地のみを対象にしているため, 1984 年 5 月 21 日と 1985 年 5 月 24 日の 2 時期データを用
いても秋蒔小麦畑や牧草地は植生があるので腐植 含量推定の対象からはずれてしまう。そこで，裸 地はソイル・ラインから直接推定し, 植生のある 畑の場合には $\log \mathrm{TM} 3$ を裸地の $\log \mathrm{TM} 3$ 変換 し，この值から腐植含量を推定した。

まず，地力保全基本調查試坑地点のうち，1985年 5 月24日に裸地である30地点に対応する画素の $\log T M 3$ と $\log \mathrm{TM} 4$ の回帰式（2-1）を求めた。

$\log \mathrm{TM} 4=0.902 \log \mathrm{TM} 3+0.171$

$\mathrm{r}=0.997$

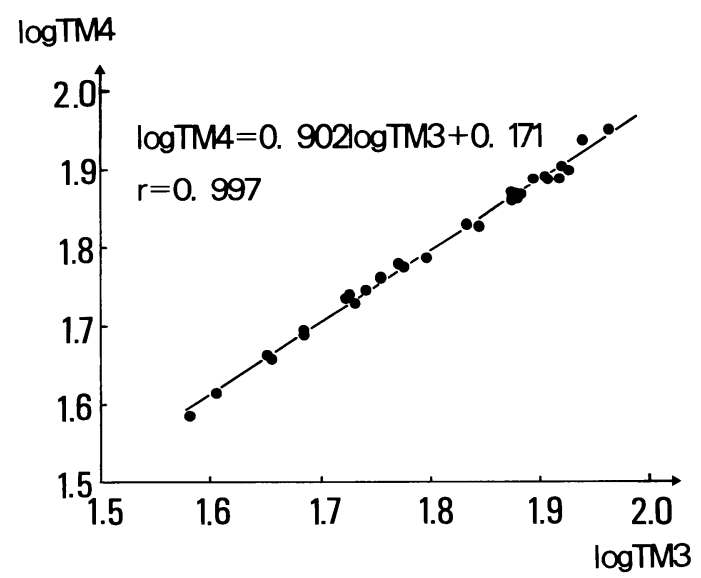

図 1 1985年のソイル・ライン・グラフ logTM3， $\log \mathrm{TM} 4$ はそれぞれ TM3，TM4のCCT 值の対数值である.

この回帰直線はソイル・ラインと呼ばれる。四 1 に このソイル・ライン・グラフを示す。ソイル・ライン 上の画素は裸地であるので植被率は $0 \%$ である。植被 率が大きくなるとその画素はソイル・ラインから離れ た位置（上方）にプロットされる。

つぎに，主対象地域の1985年 5 月24日の $\log$ TM 3 お よび $\log \mathrm{TM} 402$ 次元ヒストグラムをかくと四 2 のよ うになる。ただし，図中では対数值を次式を用いて 0 ～255の CCT 值に変換してプロットしてある。

$$
\begin{aligned}
& \text { CCT3 }=345 \log \mathrm{TM} 3-432 \\
& \text { CCT4 }=204 \log \mathrm{TM} 4-184 \\
& \text { CCT3 : 各画素の TM3の值 (CCT 值) } \\
& \text { CCT } 4 \text { : 各画素の TM4の值 (CCT 値) }
\end{aligned}
$$

困2のグラフからソイル・ラインより最も離れた頂 点の座標を読み取った $((\log \mathrm{TM} 3, \log \mathrm{TM} 4)=(1.415$, 2.286))。 


\section{CCT4（ CCT値）}

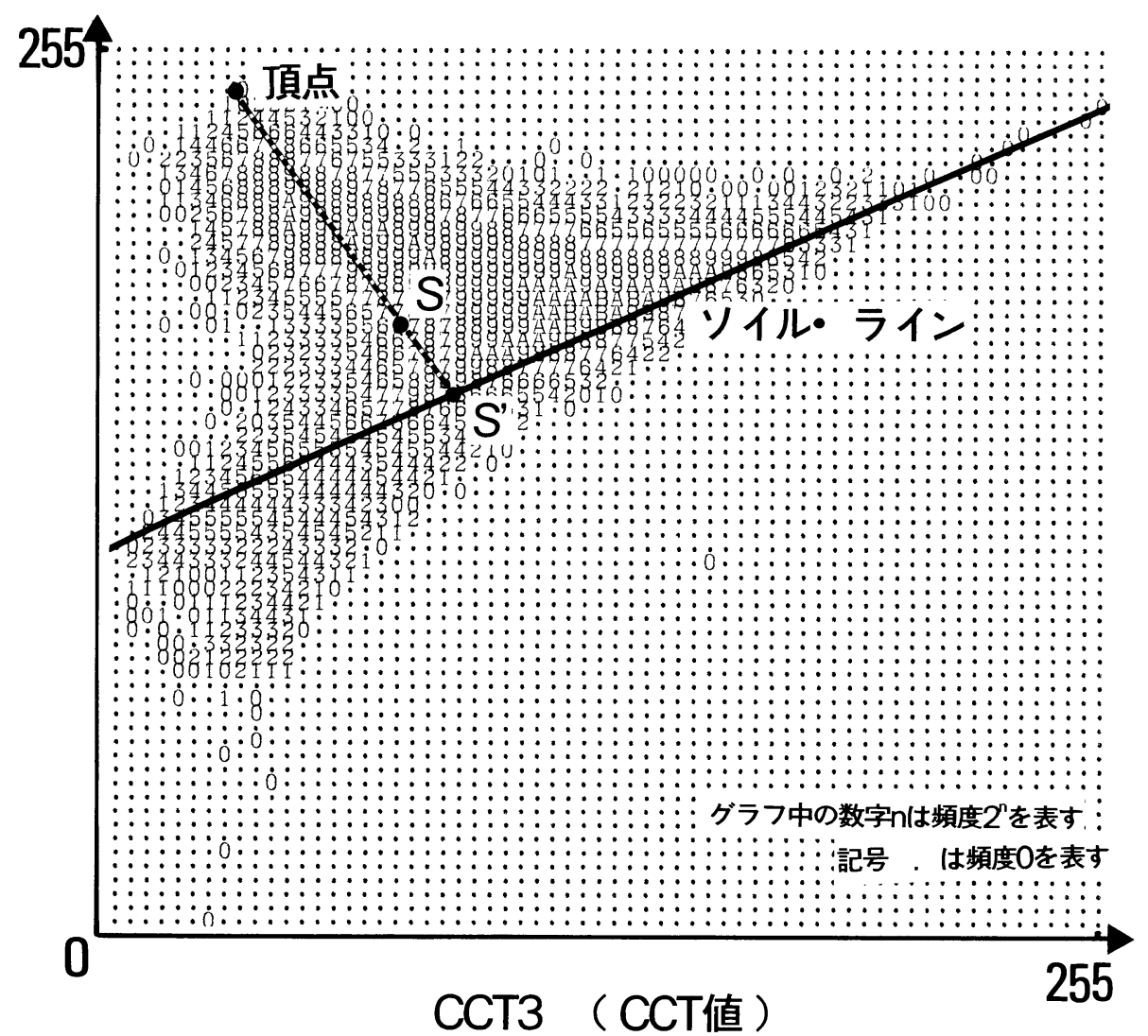

図 2 1985年 5 月24日の $\log$ TM3と $\log \mathrm{TM} 4$ の 2 次元ヒストグラム. ただし, $\log \mathrm{TM} 3$ と $\log$ TM4の值（対数值）を 0 255の值（CCT3と CCT4）に変換してある. 頂 点は植被率100\%の点である. $\mathrm{S}$ は植被のある任意の画素, $\mathrm{S}^{\prime}$ は $\mathrm{S}$ から植被の影 響を除去したもの.

この頂点は植被率が最大,つまり 100\%の点だと考え られる。頂点と各画素 $\mathrm{S}$ を通る直線を引くとその傾き は土䁃指数と呼ばれ，この直線上の各点の土壌腐植含 量は等しくなる2)。したがって,この直線とソイル・ラ インの交点 S'の $\log \mathrm{TM} 3$ 座標は, この直線上の画素か ら作物の影響を除去したものと理解して良い。この交 点 $\mathrm{S}^{\prime}$ の $\log \mathrm{TM} 3$ 座標は, 土壌指数とソイル・ラインか ら求めることができる。ある画素 $\mathrm{S}$ の座標を $(\mathrm{x}, \mathrm{y})$, 交点 S'の座標を $(\log \mathrm{TM} 3, \log \mathrm{TM} 4)$ とすると土壤指 数は次式で表される。

$$
\frac{\mathrm{y}-2.286}{\mathrm{x}-1.415}=\frac{\log \mathrm{TM} 4-2.286}{\log \mathrm{TM} 3-1.415}
$$

これを $\log \mathrm{TM} 4$ について解き, ソイル・ラインの式 (2-1) に代入すると交点 S'の $\log \mathrm{TM} 3$ 座標は次式のよ
うになる。

$$
\log \mathrm{TM} 3=\frac{2.115 \mathrm{x}-1.415 \mathrm{y}+0.242}{0.902 \mathrm{x}-\mathrm{y}+1.010}
$$

式 (2-2a)，(2-2b)をそれぞれ $\log$ TM $3 ， \log$ TM4につ いて解き，(2-3) 式に代入すると

$$
\log \mathrm{TM} 3=\frac{0.006 \mathrm{CCT} 3-0.007 \mathrm{CCT} 4+1.615}{0.003 \mathrm{CCT} 3-0.005 \mathrm{CCT} 4+1.237}
$$

となる。(2-4) 式で交点 S'の $\log$ TM 3 座標を求めた後, これを画像データとして扱うために（2-2a）式を再び 適用して $0 \sim 255$ の CCT 值に変換した。この值を変換 TM3と呼ぶことにする。

変換 TM3から土壌腐植含量を推定するために地力

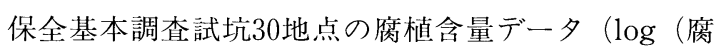




\section{変換 $\mathrm{TM} 3($ CCT値 $)$}

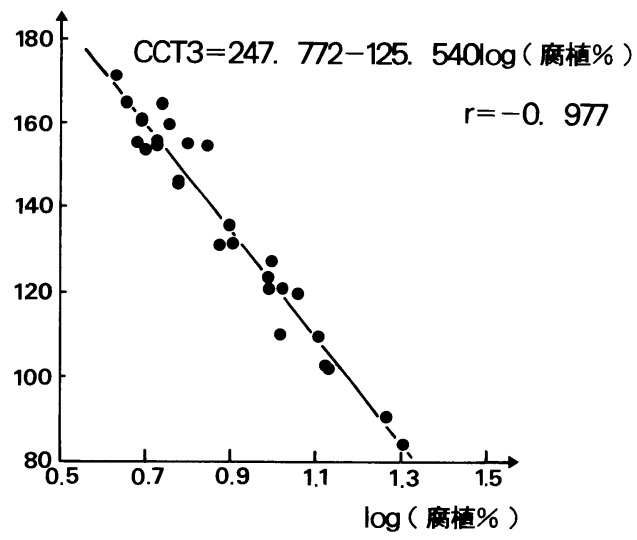

図3 $\log ($ 腐植\%）と変換 TM3との関係

変換 TM3は，各画素の $\log \mathrm{TM} 3$ から植被の影響を 除去した值を 0 ～255の CCT 值に変換したもので ある。

植\%）とその地点に対応する画素の変換 TM3との回 帰式を求めた（図 3 )。

変換 TM3 $=247.772-125.540 \log （$ 腐植\%）

$$
\mathrm{r}=-0.977
$$

この式から腐植含量 $2 ， 5 ， 8 ， 10 ， 12 ， 15 \%$ に対応 する変換 TM3の值 $209,160,134,122,112,100$ を求 め, 腐植区分值とした。

\section{(4) 土壤腐植区分図の作成手順}

ランドサット TM データからの土壌腐植区分四作 成手順を四 4 に示す。まず，1984年 5 月21日と1985年 5 月24日のそれぞれの TM3 TM4デー夕は, 十勝管 内土壌分類図6)の土壌図が描かれている範囲がパス一 ロウ106-30と106-31にまたがっているため, 両シーン で重複している部分の CCT 值の単回帰式を使ってパ スーロウ106-31の CCT 值をパスーロウ106-30の CCT 值レベルに合わせた後, 雨シーンをつなぎ合わせ た。また，1984年 5 月 21 日のデータと1985年 5 月 24 日 のデータでは各画素の CCT 值のレベルが異なってい るので, 土壌腐植含量を推定する前に雨データのレべ ルを合わせる必要がある。(1)1984年と1985年では腐植 含量は変化しないと考えて良い，(2)裸地または植被率 の小さい地点は $\log \mathrm{TM} 3$ と $\log \mathrm{TM} 4$ の散布図上でソイ ル・ライン付近にプロットされる，という２点に注目 して, 地力保全基本調査試坑地点（ソイル・ライン上 にプロットされている)の両年の $\log \mathrm{TM} 3, \log \mathrm{TM} 4$ そ
れぞれの単回帰式を求めた。

$\log \mathrm{TM} 3_{1985}=1.084 \log \mathrm{TM} 3_{1984}-0.156$

$\log \mathrm{TM}_{1985}=0.994 \log \mathrm{TM}_{1984}+0.048$

1985年のデータとこの回帰式により変換した1984年の デー夕からそれぞれの年の土壌腐植含量を画素ごとに 推定し，それを腐植含量と $\log \mathrm{TM} 3$ との単回帰式を基 に 0 〜 255の值に割り当てて土壤腐植含量推定画像を 作成した。

つぎに，1984年の植被率の判定に用いるために 1984 年のデー夕を用いて各画素を通りソイル・ラインに平 行な直線の $\mathrm{y}$ 切片の值 VI を次式から計算し, VI 值画 像を作成した。

$$
\begin{aligned}
\mathrm{VI}= & (\log \mathrm{TM} 4-0.902 \log \mathrm{TM} 3-0.171) * 100+ \\
& 100
\end{aligned}
$$

5 月の带広地域の畑は裸地，裸地に近い畑地（秋播 小麦）および植生のある畑地（牧草地）に大別される ので，土㙵腐植含量推定画像から裸地とそれに近い畑 地および牧草地を抽出するために1985年10月15日の データを用いて判別ファイルを作成した。土地被覆分 類から判別ファイルを作成するために1985年 7 月 27 日 のデータを1985年10月15日のデータにつなぎ合わせた 後，5月のデータと同じ範囲を 7 バンド切り出した。 この 7 バンド・デー夕に対して主成分分析・最尤法分 類を行い, 畑 (麦) - 畑 (裸地) - 水はけの悪い畑・疎 林・牧草地・薮 (新しい牧草地) - 渓畔林・森林・开开 地・水面の 10 力テゴリに区分した。土地被覆分類結果 と現地の状況をつき合わせたところ，畑（麦・裸地）・ 水はけの悪い畑・疎林および未分類の地点が裸地とそ れに近い畑地に相当したので，これらに区分された画 素を取り出して1985年の裸地畑用判別ファイルを作っ た。薮と分類された地点は新しい牧草地が多く含まれ ていたので, 牧草地と薮に分類された画素を取り出し て1985年の牧草畑用判別ファイルを作った。

1985年の裸地畑用判別ファイルを用いて1985年の土 壌腐植含量推定画像から裸地とそれに近い畑の画素を 抽出し，1985年の裸地とそれに近い畑地の腐植含量推 定画像を作成した。次に牧草地の腐植含量推定画像の 作成であるが，牧草地は一般に地表がほとんど見えな いほど植生に覆われているため, $\log$ TM3と $\log T$ M4 の散布図上でソイル・ラインから大きくはずれ，推定 した腐植含量の誤差は大きい2)。しかし，1985年は牧草 地でも前年（1984）は牧草地になっていなかった可能 性がある。そこで，1985年の牧草畑用判別ファイルを 


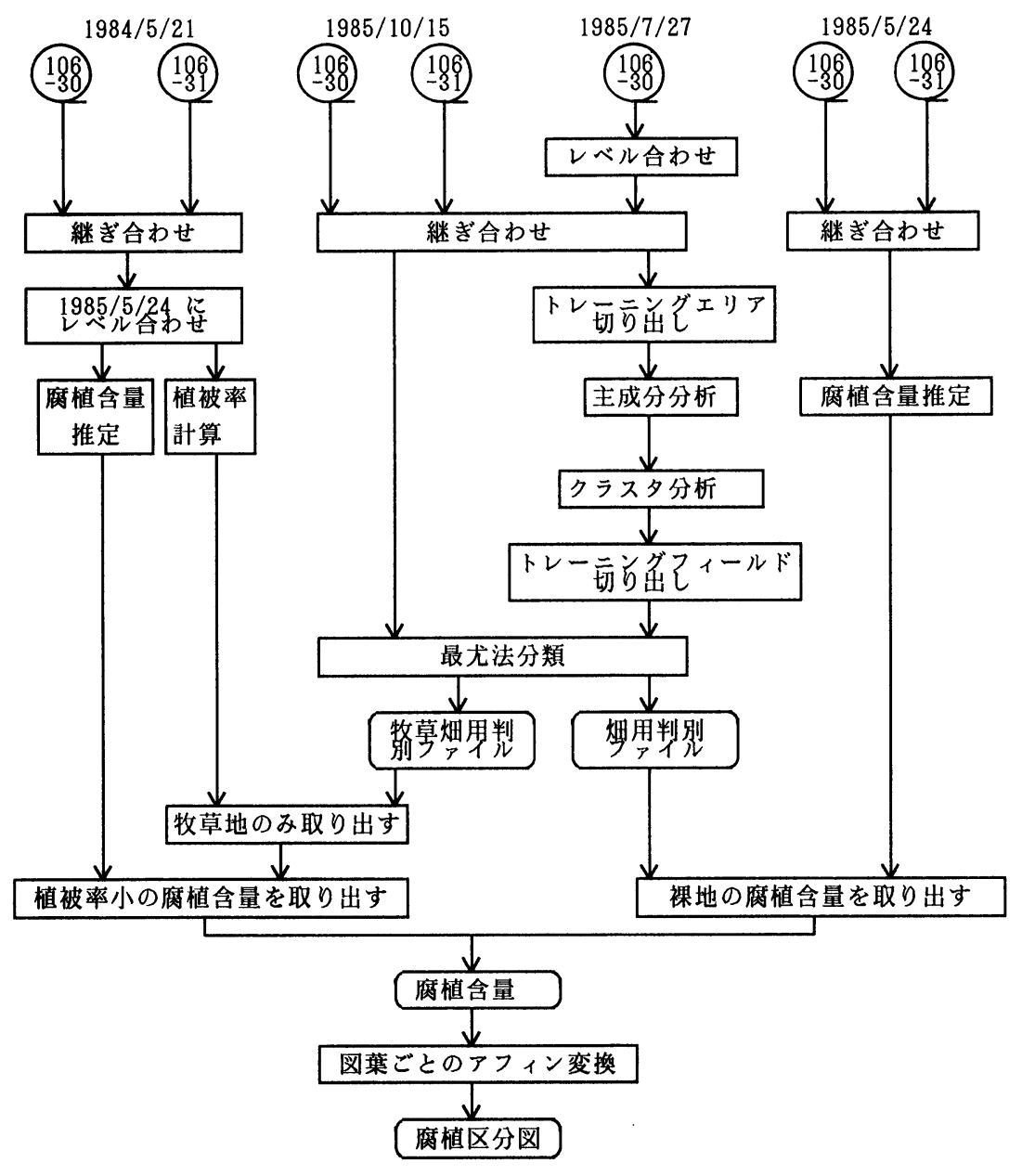

図 4 土㙵腐植区分図作成フロー

$\square$ は処理内容

用いて，1984年のVI值画像から1985年には牧草地に なっている地点の1984年の VI 值画像を作成した。そ

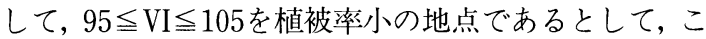
のVI値画像を用いて1984年の土壌腐植含量推定画像か ら植被率小の地点を抽出した。これが「1985年には牧 草地となっているが1984年には植被率が小であった」 畑地の腐植含量推定画像である。この画像に1985年の 裸地とそれに近い畑地の腐植含量推定画像を重ね合わ せて帯広地域全体の腐植含量の推定画像とした。この 画像中には，実際には畑地であっても推定対象外と判 定されてしまった画素もある。そこで，畑地の中に 1
画素だけ存在するこのような画素（穴）は，当該画素 を挟む 2 画素の腐植含量の平均值で補完した。これを 18図葉の基図に合わせて切り出し，画像の向きが地図 と同じ北向きになるように，そして 1 画素が $28.5 \mathrm{~m}$ 四 方から $25 \mathrm{~m}$ 四方になるようにアフィン交換した。各図 葉を個別に変換したのは，隣接した図葉との接合性よ りも，基図（縮尺 1：50,000の地形図）との整合性を 重視したためである。これを基に腐植含量 $0 ， 2 ， 5$, $8 ， 10 ， 12 ， 15 \%$ で区分し，地形図上にコンピュー夕・ マッピングして土㙵腐植区分図を完成させた。 


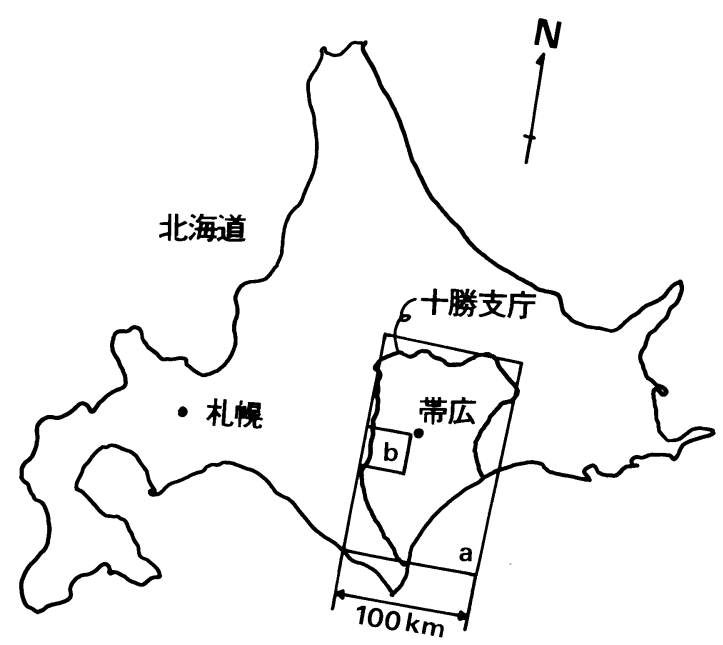

図 5 土壌鹰植区分図の範囲

a 土培植区分四18図葉全域

b 例として取り上げたNo.12芽室・帯広図幅

\section{3. 結果と考察}

作成した土堙腐植区分図は図 5 に示すように北海道 带広地域（十勝支庁）をほとんどカバーしている。本 腐植区分図の図葉割は，带広地域で基盤整備事業等に 最もよく使われている十勝管内土潩分類図 ${ }^{6}$ に合わせ た。腐植区分図作成の当初の目的が土㖶図の補完であ るので,この土壌罒を各図葉ごとにオーバーレイ・シー トとして経じ込んだ。本土㙵腐植区分罒のNo.12芽 室·带広図幅に対応する画像を写真 1 に示す。さらに, この図幅に対応する土㙵図を図 6 に示す。

土堙腐植含量の推定に抢いて，各画素の TM3の CCT 值をそのまま使う代わりに, $\log \mathrm{TM} 3-\log \mathrm{TM} 4$ 座標空間で頂点および各画素を通る直線とソイル・ラ インとの交点の $\log \mathrm{TM} 3$ 座標を求めた。この值を使う ことにより裸地だけでなく，秋播小麦畑や新しい牧草 地のように植被率の低い畑地の腐植含量も植被の影響 を除去して推定できた。

腐植区分図は 1 画素の大きさが $25 \mathrm{~m}$ 四方で，縮尺 1 ： 50,000地図との重ね合わせの䛊差が 1 画素以内 (印刷時のズレは除く)で作成できた。一方，土壤図は 500m 四方 (25ha) に 1 点の試坑に基づき地形を考慮し て作られている場合が多いため，図 6 に示すように滑

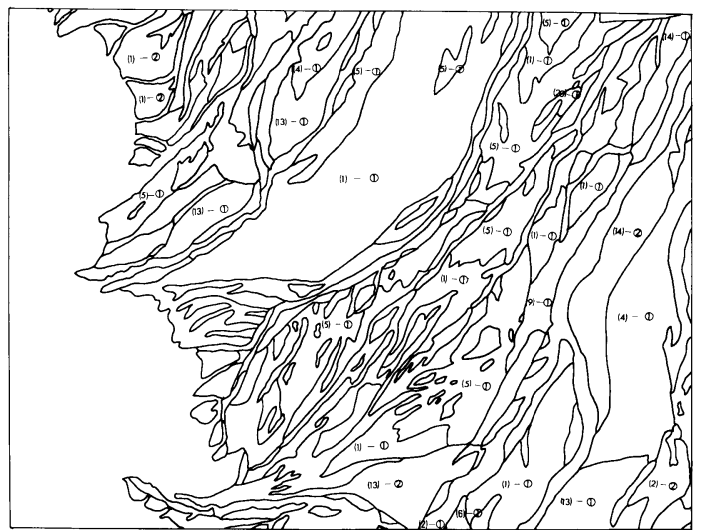

図 6 土塞図（十勝管内土壌分類図）

No.12芽室・带広困幅にオーバーレイされる部分. 本 図幅の範团は 4 土塞型 22 土蚺属からなるが，そのう ち四中に土䁃属 No.一土堙区 No.を記したものを下 に示す。

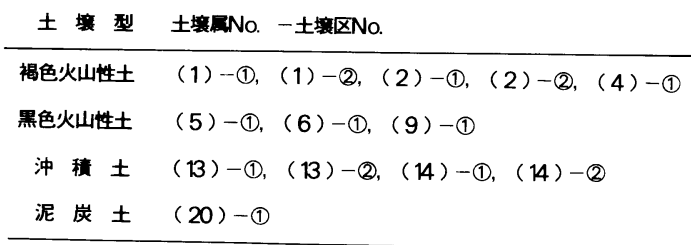

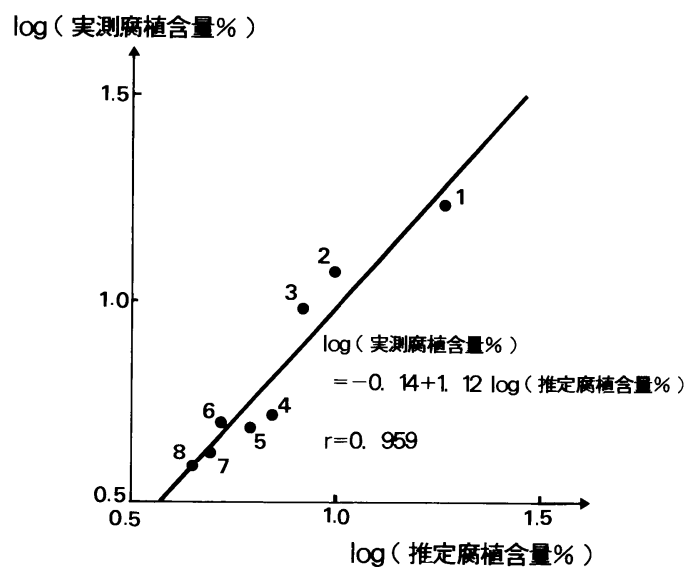

図 $7 \log ($ 推定腐植含量\%）と $\log$ （実測腐植含量\%）と の関係
1, 2: (6 ) -(1) 黒色火山性土
3: （2）-(2) 褐色火山性土
4: （13）－(1) 沖積土
5: (13) -(2) 沖積土
6: （2）-(1) 褐色火山性土
7: （14 )-(2) 沖積土
8: （2）-(1) 褐色火山性土 


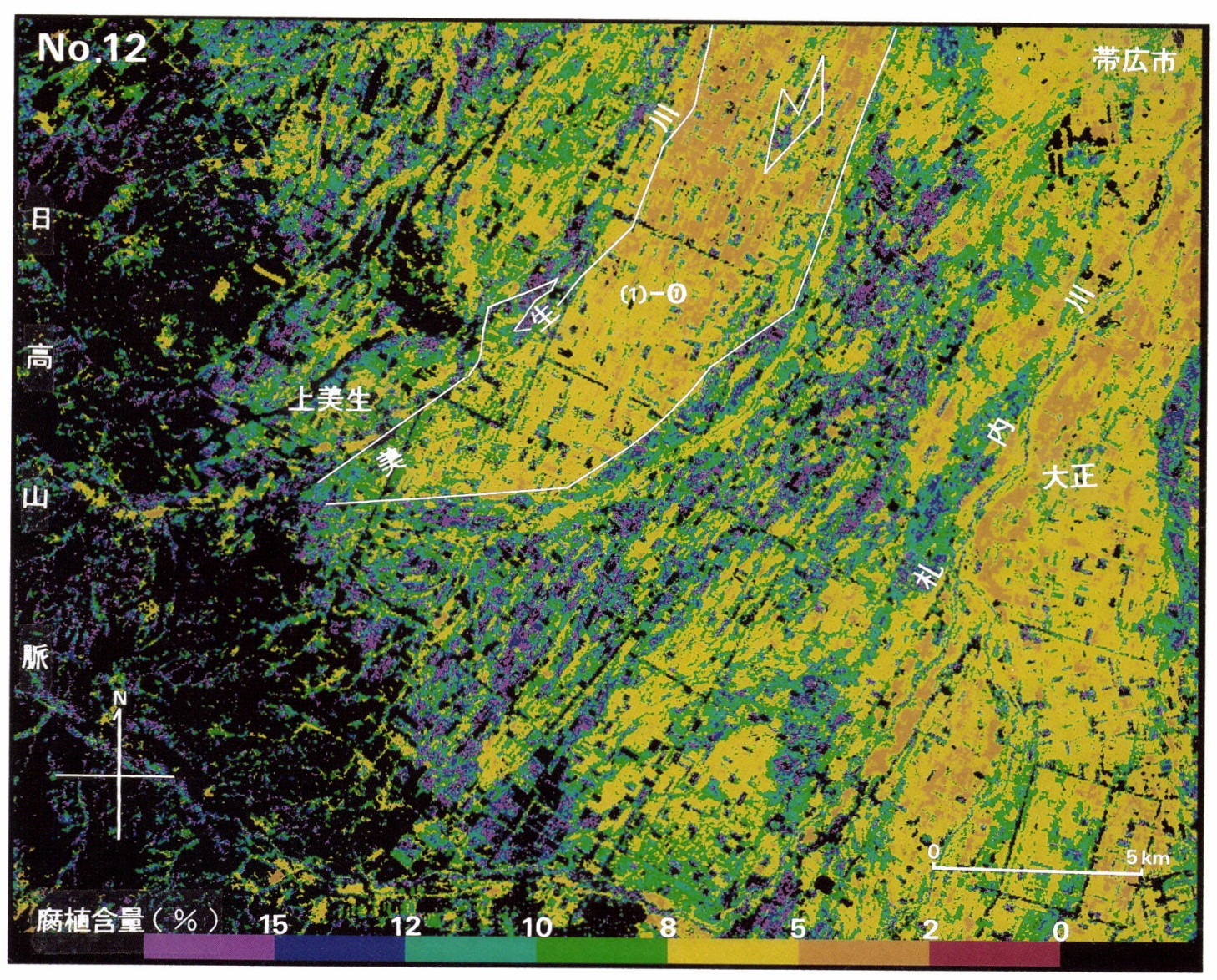

写真 1 土壤腐植区分画像

No.12芽室・带层図幅。写真中に例として(1)一(1)褐色火山性土のくくり線を大

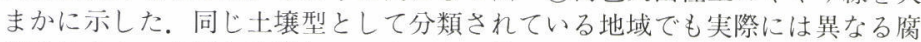
檤含量をもつ土壌が出現していることが見てとれる.

\section{色 調 腐植含量 ( \%)}

\begin{tabular}{ll}
\hline アカ & $0 \sim 2$ \\
オレンシ & $2 \sim 5$ \\
キイロ & $5 \sim 8$ \\
シドリ & $8 \sim 10$ \\
シアン & $10 \sim 12$ \\
アオ & $12 \sim 15$ \\
ムラサキ & 15以上 \\
\hline
\end{tabular}

らかな線で土堙統をくくってある。そのため, 両者を 重ね合わせてみると(写真 1 に例として(1)-(1)褐色火山 性土のくくり線を示した), 同じ土壤統とされていたも のも複数の腐植含量区分階級に分けられている。した
がって，土猿腐植区分図作成の当初の目的である土壌 図の補完は達成されたものと考える。

一般に腐植含量は階級区分が連続的に変化するが, 場所によっては隣接する階級を越えて不連続に変化す 
ることがある。例えば，腐植含量の多いところに極端 に少ない土壤がある場合で, 深耕により下層土が出現 しているか, 客土が考えられる。逆は，地形的にはく ぼ地の場合が多い。

土壤四に示されているように帯広地域の土壤は火山 性土, 沖積土, 泥炭土などから構成されている。 $\log \mathrm{TM} 3$ と $\log ($ 腐植含量\%) との関係のグラフは土壌 型によらず直線になる5のので, 本研究ではどの土壤型 も同じ推定式で腐植含量を推定した。推定した腐植含 量の精度を検討するために，对象地域内の主な土壌型 である褐色火山性土, 黒色火山性土, 沖積土の 8 地点 から採取した土壌の腐植含量と推定値が一致するか否 かを検討した。その結果，両者はほぼ1：1に対応し， 相関係数は 0.959 と高かった（図 7 )。したがって，推 定腐植含量を用いても精度上の問題はないと認められ る。

写真 1 で黒い部分は, 非裸地, または植被率が大と 判定されたために腐植含量の推定対象からはずれた画 素である。土地被覆分類において市街地というカテゴ リを設けなかったため, 市街地が裸地または疎林に区 分されて腐植含量の推定対象となってしまった。また, 写真 1 には現れていないが, 山頂付近の残雪の影響を 完全に除去できなかったため, 残雪の外縁部が腐植含 量の推定対象になり，0〜2\%に区分された。これら は今後解決すべき問題である。さらに, 植被率の大き い畨場（主に牧草地）が圃場単位で腐植含量の推定対 象からはずれている。このような戋場に対しても有効 な精度の高い腐植含量の推定方法の開発も今後の課題 である。

\section{ま と め}

畑地灌溉や排水改良等土地基盤整備, 土䁃改良, 作 付け計画, 肥培管理等に活用するために，ランドサッ トTMデー夕を用いて帯広地域の畑地を対象とした 18図葉からなる縮尺 $1 ： 50,000$ の土壤腐植区分図を作 成した。本腐植区分図の特徵は(1) 1 画素の大きさが 25 m であること, (2)腐植含量の割合を 7 レベルに区分し たことである。腐植区分図と地困との重ね合わせの䛊 差は 1 画素以内である。腐植含量は 1 画素内の平均值 を表している。したがって，本腐植区分図は土壤の特 徴を圃場単位で把握でき, きめ細かな技術対策をたて る上で有効である。

\section{謝辞}

本研究は北海道農業試験場畑土壌管理研究室西宗昭 室長, 新良力也研究員らとの共同研究の一環として 行った。また, 米林仲氏 (現千葉県立中央博物館), 高 山晴夫氏（現鹿島建設株式会社技術研究所）の協力を 得た。ここに謝意を表します。

\section{参 考 文 献}

1) 福原道一 (1975)：土壌のリモートセンシング, リモー トセンシング, キャノンイメージ, 165 178.

2 ) Fukuhara, M., Hayashi, S., Yasuda, Y., Asanuma, I., Emori, Y. and Iisaka, J. (1979) : Extraction of soil information from vegetated area. Machine Processing of Remotely Sensed Data Symposium, 242 252.

3 ) 福原道一 (1987)：先端技術による日本農業の展開 [1] 一開発応用の現状——ランドサット利用による土堙の 情報化とその応用，農業および園芸，62，827～ 830 .

4) 福原道一・西宗昭・畠中哲哉・斎藤元也・岡本勝男・新 良力也・白崎公嗣・染井順一郎（1989）：帯広地域土猿腐 植区分図，北海道開発局帯広開発建設部，24pp.

5 ）畠中哲哉・塩崎尚郎・福原道一・宮地直道・斎藤元也 (1989）：ランドサットTM デー夕による畑地表土の腐 植含量評価, 日本土㙵肥料学雑誌, $60,426 \sim 431$.

6 ）菊地晃二・関谷長昭・横井義雄（1973）：十勝管内にお ける土壤の分類 ・特徵及び改良法, 北海道十勝支庁.

7 ）気象庁 (1984): 昭和59年 5 月全国気象表, 気象庁月報.

8 ) 気象庁 (1985): 昭和60年 5 月全国気象表, 気象庁月報.

9 ) 岡本勝男・福原道一・畠中哲哉 (1990): 带広地域土壌 腐植区分図の作成, 日本写真測量学会平成 2 年度年次学 術講演会発表論文集, $13 \sim 18$.

10）志賀弘行・福原道一・小川茂男（1989）：ランドサット TM デー夕による湛水下水田の腐植含量推定, 日本土堙 肥料学雑誌, $60,432 \sim 436$.

11）真行寺孝・渡辺春朗・福原道一（1989）：樑耕による表 土腐植含量の低下に関する調查—ランドサット TM データによる解析一一, 日本土堙肥料学会講演要旨集, 35,10 . 